DOI: http://dx.doi.org/10.33846/hn50104

http://heanoti.com/index.php/hn

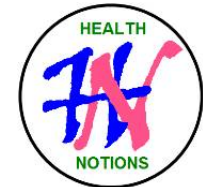

RESEARCH ARTICLE

URL of this article: http://heanoti.com/index.php/hn/article/view/hn50104

\title{
The Effect of Dandang Gendis Extract (Clinacanthus nutans) on Kidney Histopathological Features of Diabetic Rats Model
}

\author{
Miranda Jemyma Mas'ulun', Arifa Mustika ${ }^{2(\mathrm{CA})}$, Ema Qurnianingsih ${ }^{3}$ \\ ${ }^{1}$ Faculty of Medicine, Universitas Airlangga, Indonesia; miranda.jemyma.masulun-2016@fk.unair.ac.id \\ ${ }^{2(\mathrm{CA})}$ Department of Pharmacology, Faculty of Medicine, Universitas Airlangga, Indonesia; arifa-m@ fk.unair.ac.id \\ (Corresponding Author) \\ ${ }^{3}$ Department of Biochemistry, Faculty of Medicine, Universitas Airlangga, Indonesia; ema-q@ @k.unair.ac.id
}

\begin{abstract}
Changes in kidney homeostasis due to diabetes can cause oxidative stress which then caused tissue damage that leads to diabetic nephropathy. Clinacanthus nutans extract is known to contain antioxidants that are reported to play an important role in the body's defense system against oxidative stress to minimize tissue damage. This study aims to know the effect of Clinacanthus nutans leaf extract administration on kidney histopathological features of the diabetic rats model. A total of 35 rats were induced by streptozotocin which then divided into 5 groups and given Clinacanthus nutans extract with a dose of $75 \mathrm{mg} / \mathrm{kgBW}, 150 \mathrm{mg} / \mathrm{kgBW}$ and $300 \mathrm{mg} / \mathrm{kgBW}$ then compare with CMC-Na as control and metformin as standard drug for 14 days. The kidney histopathology was evaluated under a light microscope against the damage criteria that occurred in the proximal tubules of the kidney. As the result the least amout of kidney damage was on treatment group at dose $300 \mathrm{mg} / \mathrm{kgBW}$, followed by extract with dose 75 $\mathrm{mg} / \mathrm{kgBW}, 150 \mathrm{mg} / \mathrm{kgBW}$, and metformin. In conclusion Clinacanthus nutans extract with a dose of $75 \mathrm{mg} / \mathrm{kgBW}$, $150 \mathrm{mg} / \mathrm{kgBW}$, and $300 \mathrm{mg} / \mathrm{kgBW}$ can improve the kidney histopathological feature of the diabetic rats model.
\end{abstract}

Keywords: diabetes mellitus; histopathology; diabetic nephropathy; Clinacanthus nutans

\section{INTRODUCTION}

There are approximately 10.3 million adults aged 20-79 years with diabetes in Indonesia which makes Indonesia the sixth highest in the world in 2017 and in 2045 it is estimated that the number of diabetics in Indonesia will reach 16.7 million people ${ }^{(1)}$. Complications that most affect patients with diabetes mellitus are abnormalities of the blood vessel system as a result of metabolic complications. Kidney is an organ that is rich in micro vascularization and is sensitive to changes in hemodynamic and metabolic conditions, which makes it a vulnerable target for changes in the microenvironment ${ }^{(2)}$. Data collected from 54 countries reveal that more than $80 \%$ cases of end-stage kidney disease are caused by diabetes, hypertension, or a combination of both. The prevalence of end-stage kidney disease is 10 times higher in people with diabetes compared with those who don't $t^{(3)}$.

Diabetes mellitus (DM) is a metabolic disease with symptoms of hyperglycemia as a result of lack of insulin production due to pancreatic beta cell dysfunction, increased cellular resistance to insulin, or both ${ }^{(4)}$. If blood sugar levels in diabetes mellitus are not maintained, complications can occur, one of them is diabetic nephropathy, which is a condition in which there are changes in kidney structure due to excessive blood sugar. Because of the hemodynamic and metabolic imbalances, kidney will undergo structural changes that result in progressive disruption of kidney function. Kidney disease due to diabetes (diabetic nephropathy) is one of the leading causes of terminal kidney failure and the highest death among other complications of diabetes mellitus ${ }^{(2)}$. Reactive oxygen species (ROS) play an important role in the pathogenesis of diabetes complications because, in persistent hyperglycemia, ROS production is increased. An increase in excessive ROS production and a weak antioxidant defense system support an increase in oxidative stress ${ }^{(5)}$. Oxidative stress can cause the oxidation of important macromolecules including proteins, lipids, carbohydrates, and DNA. This important macromolecular oxidation will also cause tissue damage ${ }^{(6)}$. Antioxidants are believed to play an important role in the body's defense system against ROS so as to minimize tissue damage ${ }^{(7)}$.

Clinacanthus nutans Lindau which is commonly known as dandang gendis or 'snake grass' is one of the important species of the family Acanthaceae. Clinacanthus nutans, which has been used as a herbal medicine in Malaysia, Indonesia, Thailand, and China, is believed to have various potentials treatung various disease including skin rashes, insect and snake bites, lesions due to herpes simplex virus, gout, and diabetes ${ }^{(8)}$. Ethanol extract of 
Clinacanthus nutans is reported to have anti-diabetic properties and has been tested to contain antioxidants such as flavonoids, saponins, and tannins ${ }^{(9)}$.

Flavonoids can modulate carbohydrate and fat metabolism, reduce hyperglycemia, dyslipidemia and insulin resistant, increase adipose tissue metabolism, and reduce oxidative stress and signaling pathways that are sensitive to stress and inflammatory processes, reduce apoptosis, and increase proliferation of pancreatic $\beta$ cells ${ }^{(10,11)}$. Clinacanthus nutans cultivation is fairly easy because it is enough to spread the seeds to moist soil, dry them, or cut the stems ${ }^{(12)}$. That means Clinacanthus nutans is easily cultivated and economical enough for alternative diabetes therapies. Based on the reasons above, authors are interested in conducting research on the effect of ethanolic extract of Clinacanthus nutans on the histopathological features of diabetic rats model.

\section{METHODS}

This study was an experimental research with a complete randomized design. A total of 35 male white rats (Rattus norvegicus) Wistar strains were being used. These rats then induced by streptozotosin (STZ) and then given a treatment in the form of extracts of Clinacanthus nutans with a dose of $75 \mathrm{mg} / \mathrm{kgBW}, 150 \mathrm{mg} / \mathrm{kgBW}$, and $300 \mathrm{mg} / \mathrm{kgBW}, 1000 \mathrm{mg} / \mathrm{x}$ metformin, and untreated control (Only with CMC-Na). The parameter we measured was a histopathological feature of the diabetic model Rattus norvegicus Wistar strain's kidney

Total of 35 rats were induced by streptozotocin $50 \mathrm{mg} / \mathrm{kgBW}$ which was then after 2 days after induction if random blood sugar was measured above $200 \mathrm{mg} / \mathrm{dl}$, rats were divided into 5 groups and given Clinacanthus nutans leaf extract according to the dose i.e $\mathrm{K} 1(75 \mathrm{mg} / \mathrm{kgBW}), \mathrm{K} 2(150 \mathrm{mg} / \mathrm{kgBW})$, and $\mathrm{K} 3(300 \mathrm{mg} / \mathrm{kgBW})$ then compare with $\mathrm{K} 0$ (CMC$\mathrm{Na}$ as a control) and $\mathrm{K} 4$ (metformin $1000 \mathrm{mg} / \mathrm{kgBW}$ as a standard drug). After 15 days, the rats were terminated with eter and the kidneys were harvested and fixed in $10 \%$ formalin for 24 hours and then blocked in paraffin.

After blocked in paraffin, slices (2-micron thickness) were stained with Hematoxylin-Eosin using standard protocols. The examination was carried with the reversible and irreversible damage criteria that occurred in the epithelial cells of proximal tubules of the kidneys. The irreversible damage in question is necrosis, characterized by loss of the nucleus, cell fragmentation, and release of cytoplasmic contents. The reversible damage in question is surface blebs, increased eosinophilic density in the cytoplasm, and cell swelling ${ }^{(13)}$. At least 5 images were randomly captured with Olympus CX23 light microscope at 200× magnification using cellSens software (ver.2.3, Olympus Corporation, Shinjuku, Tokyo, Japan). The reversible and the irreversible cells were counted manually with the help of Cell Counter in ImageJ software ver.1.52a.

The data analysis was performed by a non-parametric test in SPSS software ver.16.00. The median and interquartile range were used as descriptive statistics. Because according to the Shapiro-Wilk test the variables were found not to be normally distributed among groups, Kruskal-Wallis and Mann-Whitney were used to make pairwise comparisons.

\section{RESULTS}

Table 1. Mean and standard deviation of kidney damage percentage

\begin{tabular}{cccc}
\hline Group & $\mathrm{n}$ & Mean & Standard Deviation \\
\hline K0 & 7 & $63 \%$ & $8 \%$ \\
K1 & 6 & $21 \%$ & $4 \%$ \\
K2 & 7 & $29 \%$ & $9 \%$ \\
K3 & 5 & $19 \%$ & $4 \%$ \\
K4 & 5 & $37 \%$ & $16 \%$ \\
\hline
\end{tabular}

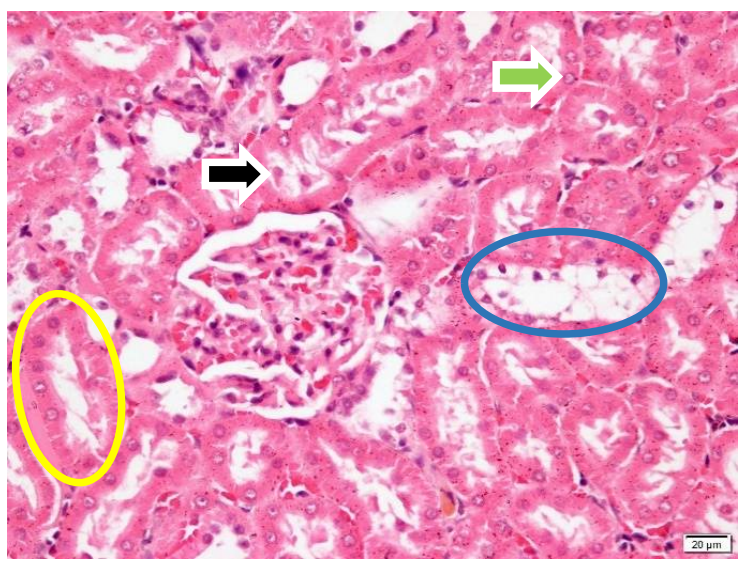

Figure 1. Histopathological features of Rattus norvegicus kidney with STZ induction and treatment with $C$. nutans dose $300 \mathrm{mg} / \mathrm{kgBW}$. Black arrow = irreversible damage/necrosis, Green Arrow = reversible damage/degeneration. Yellow circle $=$ proximal tubule. Green circle $=$ distal tubule $(\mathrm{HE}, 400 \mathrm{x})$. 
The results of histopathological examinations on the kidney tissues are shown in Table 1. As can be seen, the group with the least amount of proximal tubule's epithelial cell damage was the group with the administration of Clinacanthus nutans extract at a dose of $300 \mathrm{mg} / \mathrm{kgBW}$ followed by the group with a dose of $75 \mathrm{mg} / \mathrm{kgBW}$, $150 \mathrm{mg} / \mathrm{kgBW}$, and the metformin group. The control group had the most damage. For the dose of $300 \mathrm{mg} / \mathrm{kgBW}$ and $75 \mathrm{mg} / \mathrm{kgBW}$ there was no significant difference ( $>$ >0.05). But, there's a significant difference between treatment group $300 \mathrm{mg} / \mathrm{kgBW}$ and $150 \mathrm{mg} / \mathrm{kgBW}$ and between $150 \mathrm{mg} / \mathrm{kgBW}$ and $75 \mathrm{mg} / \mathrm{kgBW}$. However, The treatment group with a dose of $300 \mathrm{mg} / \mathrm{kgBW}, 150 \mathrm{mg} / \mathrm{kgBW}, 75 \mathrm{mg} / \mathrm{kgBW}$ shows a significant difference with metformin and control group $(\mathrm{p}<0.05)$. The control group had the most damage.

\section{DISCUSSION}

Rats were induced with streptozotocin (STZ) to make a diabetes mellitus model. Streptozotocin affect glucose oxidation and decrease insulin biosynthesis and secretion ${ }^{(14)}$. Through the GLUT2 glucose transporter, STZ enters the pancreatic $\beta$ cells causing decreased expression of GLUT2 which results in increased insulin resistance and increased blood glucose levels due to decreased sensitivity of peripheral insulin receptors ${ }^{(15)}$. Diabetic nephropathy is a microvascular complication of diabetes mellitus. Clinically microalbuminuria is an early biomarker of diabetic nephropathy, but recent findings indicate that the proximal tubule has an important link in the development of diabetic nephropathy and is an alternative clinical approach for early detection of kidney disease due to diabetes ${ }^{(16)}$.

In diabetic nephropathy the proximal tubules undergo various structural changes such as tubular atrophy, interstitial fibrosis, and peritubular capillary rarefaction, each of which is closely related to decreased kidney function. Because of their high energy requirements and dependence on aerobic metabolism, proximal tubules are prone to ischemic injury in diabetes as a consequence of increased consumption. This pathophysiological disorder joins a non-ischemic mechanism to induce apoptosis and fibrosis in the nephron which simultaneously causes chronic loss of function and a tendency for acute renal failure. Diabetes-induced injury to the proximal tubules also leads to the pathology of glomerular diabetic nephropathy and postglomerular hypoperfusion, whereas interstitial fibrotic expansion suppresses and subsequently disrupts the local microvascular system namely the renin-angiotensin system ${ }^{(17)}$.

The percentage of renal proximal tubular cell damage in the control group that induced with streptozotocin without therapy had the most amount. This shows that in STZ induced diabetic rats there is kidney damage and if given diabetes therapy will improve. Oxidative stress plays an important role in the progression and development of diabetes and its complications $^{(18)}$. Various clinical studies and experimental models show that in diabetes mellituscell damage occurs, involve apoptosis and autophagy as a result of oxidative stress and the release of $\operatorname{ROS}^{(19)}$. On the histopathological features of the kidney can be found reversible damage (Surface blebs, increased eosinophilic density in the cytoplasm, and swelling of cells) and irreversible damage (necrosis, characterized by loss of the nucleus, cell fragmentation, and release of cytoplasmic contents) in the proximal tubules of the kidney ${ }^{(13)}$.

Clinacanthus nutans leaf ethanolic extract has potential as an antidiabetic, antioxidant, and anti-inflammatory ${ }^{(20)}$. In previous studies, administration of Clinacantus nutans extract to diabetes mellitus rats model canreduceblood sugar levels ${ }^{(21)}$. In a study conducted by Khoo (2018) the active compounds of flavonoids, especially flavones, were found in ethanol extracts of leaves of cormorant leaves. Same goes for research conducted by Chelyn et al. (2014) showed that cglycoside flavones such as shaftoside, isoorientin, orientin, isovitexin, and vitexin make up the majority of the flavonoid classes found. The main mechanism in the antidiabetic activity of c-glycoside flavonoids is the inhibition of the formation of AGE, $\alpha$-glucosidase, aldose reductase, and protein tyrosine phosphatase; stimulates glycogen storage and activation of insulin signaling ${ }^{(22)}$. Flavonoids can also play a role as a radical scavengers because free radicals play an important role in the pathogenesis of inflammation in the process of kidney damage ${ }^{(23)}$. The flavonoid content can further inhibit oxidative stress which has an effect on delaying cell damage in tissues including pancreatic $\beta$ cells and renal tubular cells ${ }^{(20,24,25)}$.

The results of this study indicate that the group given Clinacanthus nutans extract $300 \mathrm{mg} / \mathrm{kgBW}$ had the smallest percentage of kidney damage than the other groups. However, these results after being tested with the Mann-Withney test were not significantly different from the groups given $75 \mathrm{mg} / \mathrm{kgBW}$ of Clinacanthus nutans extract. Those two groups after being tested with a group given $150 \mathrm{mg} / \mathrm{kgBW}$ extract there was a significant difference in both, this can be called the non-monotonic dose response, but the treatment group which was given Clinacanthus nutans extract with dose of 75 $\mathrm{mg} / \mathrm{kgBW}, 150 \mathrm{mg} / \mathrm{kgBW}$, and $300 \mathrm{mg} / \mathrm{kgBW}$ has a significantly less amount of damage compared to the control group and the group that was only given metformin $1000 \mathrm{mg}$. The occurrence of dose response with an insignificant increase indicates a non-monotonic dose response relationship. Non-monotonic dose response relationship if formed into a curve it will form the letter $\mathrm{U}$ or inverted letter $\mathrm{U}$. The mechanism for the occurrence of a non-monotonic dose response is caused by various theories, including cytotoxicity and dose-dependent modulation metabolism ${ }^{(26)}$. However, this study cannot yet explain which mechanism that makes the dose response not linear. However this proves that the administration of Clinacanthus nutans leaf extract can improve the kidney histopathological features of diabetic rats model because there is a significant reduction in the percentage of kidney damage in rats that have been induced by STZ.

\section{CONCLUSION}

Clinacanthus nutans leaf ethanolic extract with a dose of $75 \mathrm{mg} / \mathrm{kgBW}, 150 \mathrm{mg} / \mathrm{kgBW}$, and $300 \mathrm{mg} / \mathrm{kgBW}$ can improve kidney histopathological feature of the diabetic rats model. 


\section{REFERENCES}

1. International Diabetes Federation. IDF Diabetes Atlas. 8th ed. Karuranga S, Fernandes J da R, Huang Y, Malanda B, editors. 2017.

2. Magee C, Grieve DJ, Watson CJ, Brazil DP. Diabetic Nephropathy: a Tangled Web to Unweave. Cardiovasc Drugs Ther. 2017;31(5-6):579-92.

3. World Health Organization. Global Report on Diabetes. Vol. 978. 2016.

4. Harikumar K, Althaf SA, Kishore Kumar B, Ramunaik M, Suvarna C. A Review on Hyperlipidemic. Nternational J Nov Trends Pharm Sci. 2013;3(4):69-80.

5. Sifuentes-Franco S, Padilla-Tejeda DE, Carrillo-Ibarra S, Miranda-Díaz AG. Oxidative stress, apoptosis, and mitochondrial function in diabetic nephropathy. Int J Endocrinol. 2018;2018.

6. Forbes JM, Coughlan MT, Cooper ME. Oxidative stress as a major culprit in kidney disease in diabetes. Diabetes. 2008;57(6):1446-54.

7. Anuj Y, Rewa K, Ashwani Y, J.P. M, Seweta S, Shashi P. Antioxidants and its functions in human body - A Review. Res Environ Life Sci. 2016;9(11):1328-31.

8. Alam A, Ferdosh S, Ghafoor K, Hakim A, Juraimi AS, Khatib A, et al. Clinacanthus nutans: A review of the medicinal uses, pharmacology and phytochemistry. Asian Pac J Trop Med. 2016;9(4):402-9.

9. Abdullah N, Kasim KF. In-Vitro Antidiabetic Activity of Clinacanthus nutans Extracts. Int J Pharmacogn Phytochem Res. 2017;9(6):846-52.

10. Testa R, Bonfigli AR, Genovese S, De Nigris V, Ceriello A. The possible role of flavonoids in the prevention of diabetic complications. Nutrients. 2016;8(5):1-13.

11. Vinayagam R, Xu B. Antidiabetic properties of dietary flavonoids: A cellular mechanism review. Nutr Metab. 2015;12(1):1-20.

12. nparks.gov.sg. Clinacanthus nutans (Burm. f.) Lindau [Internet]. 2019 [cited 2020 Jan 3]. Available from: https://www.nparks.gov.sg/florafaunaweb/flora/5/6/5655

13. Kumar, Abbas, Aster. Robbin Basic Pathology. 10th ed. Kumar, Vinay. Abbas, Abul K. Aster JC, editor. Philadelphia, Pennsylvania; 2018. 1-910 p.

14. Deeds MC, Anderson JM, Armstrong AS, Gastineau DA, Hiddinga HJ, Jahangir A, et al. Single dose streptozotocin-induced diabetes: Considerations for study design in islet transplantation models. Lab Anim. 2011;45(3):131-40.

15. Firdaus, Rimbawan, Marliyati SA, Roosita K. Streptozotocin, Sucrose- Induce Diabetic Male Rats Model for Research Approach of Gestational Diabetes Mellitus. J MKMI. 2016;12(1):29-34.

16. Zeni L, Norden AGW, Cancarini G, Unwin RJ. A more tubulocentric view of diabetic kidney disease. J Nephrol. 2017;30(6):701-17.

17. Gilbert RE. Proximal Tubulopathy : Prime Mover and Key Therapeutic Target in Diabetic Kidney Disease. Diabetes. 2017;66:791-800.

18. Tiwari BK, Pandey KB, Abidi AB, Rizvi SI. Markers of Oxidative Stress during Diabetes Mellitus. J Biomarkers. 2013;2013.

19. Maiese K. without cellular demise. J Transl Sci. 2016;2(3):185-7.

20. Khoo LW, Audrey Kow S, Lee MT, Tan CP, Shaari K, Tham CL, et al. A Comprehensive Review on Phytochemistry and Pharmacological Activities of Clinacanthus nutans (Burm.f.) Lindau. Evidence-based Complement Altern Med. 2018;2018.

21. Roosita K, Kusharto CM, Sekiyama M, Fachrurozi Y, Ohtsuka R. Medicinal plants used by the villagers of a Sundanese community in West Java, Indonesia. J Ethnopharmacol. 2008;115(1):72-81.

22. Xiao J, Capanoglu E, Jassbi AR, Miron A. Advance on the Flavonoid C-glycosides and Health Benefits. Crit Rev Food Sci Nutr. 2016;56(October):S29-45.

23. Borrelli F, Izzo AA. The plant kingdom as a source of anti-ulcer remedies. Phyther Res. 2000 Dec 1;14(8):581-91.

24. Banjarnahor SDS, Artanti N. Antioxidant properties of flavonoids. Med J Indones. 2014;23(4):239-44.

25. Chelyn JL, Omar MH, Syaidatul N, Mohd A, Ranggasamy R, Wasiman MI, et al. Analysis of Flavone C Glycosides in the Leaves of Clinacanthus nutans (Burm. f.) Lindau by HPTLC and HPLC-UV / DAD. Sci World J. 2014;2014.

26. Mustika A, Indrawati R, Sari GM, Farmakologi D, Kedokteran F, Airlangga U, et al. Efek Ekstrak Daun Singawalang (Petiveria alliacea) dalam Menurunkan Kadar Glukosa Darah melalui Peningkatan Ekspresi AMPK- $\alpha 1$ pada Tikus Model Diabetes Melitus Effect of Petiveria alliacea Leaves Extract in Decreasing Serum Level of Blood Glucose Level T. J Farm Klin Indones. 2017;6(1):22-31. 